\title{
PEMBELAJARAN KOOPERATIF MODEL STAD-PROBLEM SOLVING UNTUK MENINGKATKAN MOTIVASI DAN HASIL BELAJAR MATEMATIKA PADA SISWA KELAS IV SD MUHAMMADIYAH 8 DAU MALANG
}

\author{
Erna Yayuk \\ e-mail:er_2y@yahoo.co.id
}

\begin{abstract}
The purposes of this study are to describe the implementation of learning and describe the implementation of learning outcomes with STAD-Problem Solving Model in an effort to improve the quality of processes and outcomes studied mathematics at the fourth grade students of Muhammadiyah Elementary School 8 Malang Dau. This type of research is the Classroom Action Research (CAR). Subjects were fourth grade students of Muhammadiyah Elementay School 8 Malang Dau, year 2011/2012 semester 2. The results of this study is the application of the model STAD cooperative learning, Problem Solving, can improve the quality of learning processes and results of the fourth grade math students of Muhammadiyah Elementary School 8 Malang Dau 8, year 2011/2012. The phase of learning can be explained as follows: phase 1. Preparation, phase 2. Presentation of Information Toward Problem Solving, phase 3. Working group, phase 4. Providy test / quiz on the lesson material covering, phase 5. Scoring developments, phase 6. Giving Reward, it includes.
\end{abstract}

\begin{abstract}
Abstrak: Penelitian ini bertujuan mendeskripsikan pelaksanaan dan peningkatan hasil belajar matematika siswa dengan mengunakan model STAD Problem Solving. Jenis penelitian ini adalah Penelitian Tindakan Kelas (PTK). Subyek penelitian adalah siswa kelas IV SD Muhammadiyah 8 Dau Malang tahun pelajaran 2011/2012 semester 2. Hasil penelitian ini adalah penerapan pembelajaran kooperatif model STAD-Problem Solving, dapat meningkatkan motivasi dan hasil belajar matematika siswa kelas IV SD Muhammadiyah 8 Dau Malang tahun pelajaran 2011/2012. Adapun rancangan pelajarannya dapat dijelaskan sebagai berikut: fase 1. Persiapan, fase 2 . Penyajian Informasi kearah Problem Solving, fase 3. Bekerja kelompok, fase 4. Memberikan Tes/kuis, fase 5. Memberikan skor Perkembangan, fase 6. Memberikan Penghargaan pada Kelompok.
\end{abstract}

Kata Kunci: pembelajaran kooperatif, STAD-Problem Solving, hasil belajar

Guru memiliki peran yang sangat penting dalam menentukan kuantitas dan kualitas pengajaran yang dilaksanakannya. Oleh sebab itu, guru harus memikirkan dan membuat perencanaan secara seksama dalam meningkatkan kesempatan belajar bagi siswanya dan memperbaiki kualitas mengajarnya.

Untuk memenuhi hal tersebut di atas, guru dituntut mampu mengelola proses belajar-mengajar yang memberikan rangsangan kepada siswa sehingga ia mau belajar karena siswa adalah subjek utama dalam belajar. Dalam menciptakan kondisi bela- jar-mengajar efektif harus ada partisipasi aktif dari siswa, apalagi dalam pembelajaran matematika.

Menurut hasil wawancara dengan wakil kepala sekolah dan 2 orang guru matematika SD Muhammadiyah pada tanggal 9 Mei 2011, pembelajaran di sekolah tersebut pada umumnya cenderung berorientasi pada metode ceramah. Ciri-ciri yang tampak pada pembelajaran tersebut adalah klasikal, berpusat pada guru dan kurang interaktif. Guru mengajar pada seluruh siswa di kelas pada saat yang bersamaan. Semua keputusan tentang topik-topik yang akan dipelajari 
dan susunan penyajian serta jumlah waktu yang disediakan untuk setiap topik diatur sepenuhnya oleh guru. Interaksi antara guru dengan siswa atau antara siswa dengan siswa di kelas sangat rendah. Dalam bentuk pembelajaran semacam ini, siswa hanya berperan sebagai penerima informasi secara pasif karena hanya mendengarkan dan mencatat informasi dari guru saja.

Implikasi dari pembelajaran matematika secara ceramah di atas menyebabkan pembelajaran yang terjadi kurang bermakna. Siswa lebih banyak menghafal daripada mengkontruksi pengetahuannya sendiri. Beberapa fakta tentang rendahnya kualitas proses pembelajaran tersebut adalah sebagai berikut: (a) dalam pembelajaran siswa cenderung pasif, jarang mengajukan pertanyaan, jika menemui kesulitan mereka takut bertanya, jika ada pertanyaan guru, siswa cenderung diam atau tidak bisa menjawab, (b) adanya keluhan guru yang mengajar mata pelajaran matematika, bahwa banyak siswa yang sudah kelas IV tetapi tidak menguasai konsep matematika. Seringkali yang dituding sebagai sebab kegagalan tersebut adalah kegagalan dalam proses pembelajaran matematika dan gurunya, (c) siswa memiliki ketuntasan belajar matematika berkisar sekitar 50\% - 60\% (Dokumentasi SD Muhammadiyah 8 Dau Malang).

Berdasarkan informasi di atas peneliti melakukan observasi di SD Muhammadiyah 8 Dau Malang pada tanggal 9 Mei 2011, diketahui bahwa kelas IV yang terdiri dari 28 siswa, termasuk kelas yang cenderung tidak aktif pada saat proses pembelajaran berlangsung. Pada saat peneliti melakukan observasi awal di kelas IV peneliti melihat proses pembelajaran yang berlangsung dalam kelas lebih didominasi oleh guru, sedangkan siswa cenderung pasif dalam menerima materi pelajaran yang disampaikan oleh guru. Dikatakan siswa kelas IV cenderung tidak aktif saat proses pembelajaran, karena aktivitas belajar yang dilakukan oleh siswa hanya mendengarkan penje- lasan dari guru dan mencatat yang tersaji atau tertera di papan tulis. Interaksi antara guru dan siswa atau antara siswa dan siswa di kelas sangat rendah. Selain itu pada saat guru memberi kesempatan kepada siswa untuk bertanya, siswa tidak mengajukan pertanyaan mengenai penjelasan materi yang disampaikan oleh guru. Namun ketika siswa diberi tugas berupa soal, sebagian besar siswa masih terlihat bingung dan kesulitan dalam memecahkan masalah. Hal ini menunjukkan bahwa sifat pasif siswa dalam proses pembelajaran akan mengakibatkan siswa mengalami kesulitan untuk melanjutkan kegiatan pembelajaran.

Sedangkan hasil wawancara dengan beberapa siswa kelas IV tersebut, diakui sebagian besar siswa masih mengalami kesulitan dalam menyelesaikan soal-soal yang tidak dapat dipecahkan oleh suatu prosedur rutin terutama pada pokok bahasan melakukan operasi hitung bilangan bulat dalam pemecahan masalah (Problem Solving). Hal ini dikarenakan guru jarang memberikan latihan soal pemecahan masalah matematika, siswa merasa takut dan malu bertanya jika mereka belum mengerti. Pada dasarnya kesulitan siswa dapat diatasi jika mereka berani bertanya sebelum guru melanjutkan penjelasan materi berikutnya. Sehingga kesulitan materi yang dialami siswa tidak berkelanjutan. Dalam hal ini guru pun dituntut untuk mengadakan variasi pembelajaran baik dalam penggunaan strategi pembelajaran maupun pengunaan model pembelajaran. Hal ini ditujukan agar siswa tidak mengalami kejenuhan dalam proses pembelajaran di kelas dan diharapkan dapat meningkatkan motivasi belajar siswa.

Akibat pembelajaran matematika seperti di atas, tingkat pemahaman siswa terhadap matematika rendah dan matematika dirasakan sebagai pelajaran sulit bagi sebagian besar siswa. Dalam belajar matematika banyak sekali tuntutan yang harus dipenuhi baik oleh guru maupun siswa dan seringkali tuntutan ini tidak dapat diatasi (Stieff \& 
Wilensky, 2003:287). Misalnya, agar matematika dapat dipahami dengan baik maka siswa harus menguasai tiga aspek matematika, yaitu 1) mengetahui apa saja materi matematika tersebut dan bagaimana kaitannya dengan fenomena alam, (2) memahami konsep pada mata pelajaran matematika serta memahami kaitannya dengan fenomena alam yang sesuai, (3) terampil dalam memecahkan permasalahan berkaitan dengan materi mata pelajaran matematika (Joonhston, 2000:11). Selain itu, karena kompleksnya struktur keilmuan dari matematika sendiri yang menyebabkan matematika sulit (Gabel, 1999:549), lingkungan atau atmosfer belajar tampaknya juga kurang kondusif untuk terjadinya pemahaman konsep yang optimal.

Salah satu cara untuk memahami bagaimana siswa belajar adalah melalui filosofi konstruktivisme (constructivism) yang diyakini para pakar pendidikan saat ini. Konstruktivisme memandang belajar sebagai sebuah proses sosial, bersifat dinamis dimana siswa mengkostruksi secara aktif makna dari pengalaman-pengalaman mereka dikaitkan dengan pemahaman awal dadalam kemasan setting social (Driver, etc, 1994:6). Beberapa contoh strategi pembelajaran konstruktivis adalah pembelajaraan kooperatif, learning cycle, generative learning.

Untuk meningkatkan kualitas proses dan hasil pembelajaran matematika perlu dilakukan berbagai cara, salah satu diantaranya adalah dengan menerapkan model pembelajaran yang tepat. Untuk menentukan model pembelajaran tersebut tidak mudah, harus melalui penelitian dan uji coba berulang-ulang.

Salah satu pendekatan atau strategi pembelajaran berbasis konstruktivis yaitu pembelajaran kooperatif model STAD (Student Teams Achievement Divisions) yang dikembangkan oleh Slavin pada tahun 1978 di John Hopkins University. Hasil penelitian menunjukkan bahwa model pembelaja- ran STAD dapat meningkatkan hasil belajar siswa (Supriyatiningsih, 2008). Dalam beberapa literatur lain (Solikhati, 2003) menyatakan bahwa (1) hasil belajar siswa meningkat, (2) pembelajaran tidak membosankan dan siswa merasa termotivasi untuk belajar, (3) setiap siswa terlibat aktif.

Menurut Polya (1973:7), pekerjaan pertama seorang guru matematika adalah mengerahkan seluruh kemampuannya untuk membangun kemampuan siswa dalam menyelesaikan masalah. Hal ini penting karena siswa setiap harinya selalu dihadapkan pada suatu masalah. Oleh karena itu, dalam penelitian ini akan dikombinasikan model pembelajaran STAD dengan pendekatan pemecahan masalah (Problem Solving). Problem solving merupakan suatu pendekatan pembelajaran yang sifatnya teoritis atau konseptual untuk melatihkan siswa memecahkan masalah-masalah dengan menggunakan berbagai strategi dan langkah pemecahan masalah yang ada (Billstein, 2010:2). Hasil penelitian menunjukkan bahwa berlatih dalam problem solving dapat meningkatkan kualitas proses pembelajaran (Sumarno, 2011).

Berdasarkan paparan tersebut di atas maka peneliti akan melakukan penelitian dengan judul "Pembelajaran Kooperatif Model STAD-Problem Solving untuk Meningkatkan motivasi dan Hasil Pembelajaran Matematika pada Siswa Kelas IV SD Muhammadiyah 8 Dau Malang.

\section{METODE}

Penelitian ini merupakan penelitian tindakan kelas (PTK), karena penelitian dilakukan untuk memecahkan masalah pembelajaran di kelas. Penelitian ini juga termasuk penelitian deskriptif, sebab menggambarkan bagaimana suatu teknik pembelajaran diterapkan dan bagaimana hasil yang diinginkan dapat dicapai.

PTK adalah proses investigasi terkendali untuk menemukan dan memecahkan 
masalah pembelajaran di kelas, proses pemecahan masalah tersebut dilakukan secara bersiklus, dengan tujuan untuk meningkatkan kualitas proses dan hasil pembelajaran di kelas tertentu. Dengan demikian, ciri utama PTK adalah: (1) masalahnya berasal dari latar/kelas tempat penelitian dilakukan; (2) proses pemecahan masalah tersebut dilakukan secara bersiklus, dan (3) tujuannya untuk memecahkan masalah pembelajaran di kelas atau meningkatkan kualitas pembelajaran di kelas (Akbar, 2009:26).

Sesuai dengan jenis penelitian yang dipilih, yaitu penelitian tindakan kelas, maka penelitian ini menggunakan model penelitian tindakan dari Kemmis dan Mc.Taggart (dalam Akbar, 2009: 27), yaitu berbentuk spiral dari siklus satu ke siklus berikutnya. Setiap siklus meliputi planning (rencana), action (tindakan), observation (pengamatan), dan reflection (refleksi). Langkah pada siklus berikutnya adalah perencanaan yang sudah direvisi, tindakan, pengamatan dan refleksi. Sebelum masuk pada siklus 1 dilakukan tindakan pendahuluan yang berupa identifikasi permasalahan.

Dalam penelitian tindakan ini menggunakan bentuk penelitian kolaboratif. Tujuan utama dari penelitian tindakan ini adalah untuk meningkatkan kualitas pembelajaran di kelas dimana guru secara penuh terlibat dalam penelitian mulai dari perencanaan, tindakan, pengamatan dan refleksi. Dalam penelitian ini peneliti bekerjasama dengan guru kelas, kehadiran peneliti sebagai pengajar dan dibantu dua orang observer, yaitu satu orang dosen dari PGSD UMM dan satu orang guru kelas di SD Muhammadiyah 8 Dau. Dengan cara ini diharapkan didapatkan data yang obyektif demi kevalidan data yang diperlukan.

Data yang dikumpulkan dalam penelitian ini meliputi (1) data tentang kegiatan guru dalam proses pembelajaran dengan model STAD-Problem Solving, (2) data tentang kegiatan siswa selama mengikuti kegiatan proses pembelajaran dengan model
STAD-Problem Solving, (3) data hasil belajar siswa tentang kemampuan memecahkan masalah matematika.

Instrumen yang digunakan dalam penelitian ini terdiri dari: (1) instrumen-instrumen yang berkaitan dengan proses pembelajaran. Instrumen-instrumen yang termasuk kelompok ini berupa: jurnal guru (field notes), lembar observasi untuk mengamati jalannya proses pembelajaran dan pedoman wawancara tentang persepsi siswa terhadap proses pembelajaran yang telah diikutinya. Jurnal Guru (field note) adalah berupa catatan-catatan dari hasil pengamatan guru tentang kejadian-kejadian selama proses pembelajaran berlangsung. (2) Instrumen-instrumen yang berkaitan dengan hasil belajar siswa. Instrumen-instrumen yang termasuk kelompok ini adalah soal pre test untuk mengetahui hasil belajar awal sebagai dasar pengelompokan siswa, soal post test untuk mengetahui hasil belajar akhir pada masingmasing siklus.

Teknik analisis data yang digunakan dalam penelitian tindakan kelas ini meliputi analisis kualitatif dan kuantitatif. 1) Analisis kualitatif dilakukan untuk mengetahui kualitas proses pembelajaran kooperatif model STAD-Problem Solving dari data observasi keterampilan berkolaborasi selama proses pembelajaran berlangsung, jurnal guru dan hasil wawancara siswa terhadap proses pembelajaran yang diikutinya. Hasil wawancara siswa dianalisis kemudian hasilnya diintegrasikan dengan hasil analisis data dari observasi langsung dari jurnal guru dan blangko observasi. 2) Analisis kuantitatif dilakukan untuk mengetahui hasil belajar siswa dengan melihat rata-rata skor, persentase nilai yang berkualifikasi baik dan persentase kelulusan siswa terhadap kemampuan ranah kognitif suatu materi pelajaran yang meliputi aspek-aspek sebagai berikut: pengetahuan, pemahaman konsep dan aplikasi.

Analisis data mengenai hasil belajar siswa dilakukan dengan menghitung jumlah 
siswa yang telah tuntas belajar dari kuis (post tes) dengan materi yang telah diberikan selama proses pembelajaran yaitu mengurangkan bilangan bulat.

\section{HASIL DAN PEMBAHASAN}

Pada penelitian ini, proses pembelajaran kooperatif model STAD-Problem Solving dikemas dalam bentuk diskusi kelompok untuk mencari dan memecahkan masalah, ternyata dapat menghasilkan proses pembelajaran yang berkualitas baik, walaupun ada beberapa hal yang belum optimal. Temuan ini didasarkan adanya hasil observasi selama proses pembelajaran berlangsung yang antara lain indikatornya dapat membuat siswa: (1) termotivasi dan senang untuk belajar, (2) mau dan mampu mengemukakan persoalan yang belum dikuasainya, (3) aktif berusaha memecahkan masalah baik dengan menganalisis sendiri maupun bertanya kepada temannya, (4) kreatif memanipulasi alat peraga untuk menyelesaikan masalah matematika yang ada pada lembar kerja siswa (5) mampu bekerjasama dalam kelompok secara konstruktif walaupun belum berlangsung secara optimal, (6) mampu melakukan tutorial sebaya dari siswa yang lebih pandai kepada yang kurang pandai, dan (7) mampu menghasilkan hasil diskusi yang baik berupa laporan hasil diskusi yang umumnya mempunyai skor nilai yang relatif tinggi, walaupun dalam menjawab soal kuis masih ada yang salah. Temuan tersebut sesuai dengan pendapat Hamalik (2001) yang mengatakan bahwa indikator proses pembelajaran yang berkualitas baik adalah yang mampu: (1) membuat sisswa aktif belajar, (2) menciptakan situasi yang menyenangkan siswa dalam belajar, (3) memudahkan siswa menyerap materi pelajaran, (4) menumbuhkan kesadaran belajar mandiri siswa, (5) mendorong terjadinya tutorial sebaya, (6) menumbuhkan sikap siswa yang dapat menghargai pendapat orang lain, (7) memupuk kemampuan be- kerjasama siswa, (8) menumbuhkan sikap teliti dan hati-hati pada diri siswa, (9) mendorong siswa untuk serius dalam belajar, (10) meningkatkan daya nalar/berpikir siswa, dan (11) membentuk kedisiplinan siswa.

Peran guru sangat penting di dalam proses pembelajaran. Dalam pembelajaran kooperatif model STAD-Problem Solving ini, guru memfungsikan dirinya sebagai fasilitator, mediator dan motivator. Oleh karena itu, tugas seorang guru pada pembelajaran ini adalah memandu, membimbing dan membantu siswa jika dibutuhkan. Guru membimbing dan membantu siswa melalui pertanyaan-pertanyaan arahan yang nantinya akan dikembangkan sendiri oleh siswa. Hal ini sesuai dengan pendapat Vygotsky (Slavin,1994) tentang Scaffolding, bahwa pemberian sejumlah bantuan kepada siswa selama tahap-tahap awal pembelajaran, kemudian mengurangi bantuan dan memberikan kesempatan untuk mengambil alih tanggung jawab yang semakin besar setelah ia dapat melakukannya. Scaffolding merupakan bantuan yang diberikan kepada siswa untuk belajar dan memecahkan masalah.

Dari paparan data di atas, maka dapat diketahui bahwa terjadi peningkatan terhadap keterlaksanaan aktivitas tindakan guru dari dari siklus I ke siklus II. Peningkatan disebabkan karena guru telah mempersiapkan perangkat pembelajaran dengan baik, melaksanakan pembelajaran lebih percaya diri, guru telah mampu memotivasi siswa dalam belajar dan memberikan bimbingan yang menyeluruh pada semua kelompok.

Berdasarkan temuan penelitian kegiatan siswa ini maka pembelajaran kooperatif model STAD-Problem Solving dapat meningkatkan kualitas proses pembelajaran siswa. Hal ini disebabkan karena dalam pembelajaran ini siswa berusaha menemukan konsep operasi hitung bilangan bulat melalui alat peraga, siswa mampu bekerja secara kelompok mengerjakan lembar kerja siswa serta menggunakan pengetahuannya 
untuk memecahkan masalah yang baru dalam konteks yang baru. Hal ini menyebabkan siswa menjadi lebih aktif, baik secara fisik maupun mental. Hal ini didukung pendapat Sardiman (2007:98) yang menyatakan bahwa aktivitas pembelajaran siswa akan meningkat ketika guru mampu mendorong siswa tersebut untuk berfikir dan beraktifitas dalam hal menyelesaikan masalah sesuai perkembangan kognitifnya dan berdasarkan pengalaman yang dimilikinya. Senada dengan hal tersebut, Sumarno (2011) juga menemukan bahwa berlatih dalam problem solving dapat meningkatkan kualitas proses pembelajaran matematika.

Pada siklus I pertemuan pertama, masih ada beberapa siswa yang bekerja sendiri-sendiri dalam kelompoknya, siswa belum berani mengemukakan ide dan memberi tanggapan terhadap jawaban atau penampilan temannya. Hal ini disebabkan karena siswa belum terbiasa belajar secara kelompok dan berdiskusi dengan temannya serta sifat individual siswa masih melekat. Namun setelah dilakukan motivasi dan pemberian penghargaan berupa bintang prestasi pada siklus II, keaktifan siswa menjadi meningkat cukup tajam. Mereka berlombalomba untuk memperoleh bintang prestasi sebanyak-banyaknya. Penerapan pembelajaran model STAD-Problem Solving mampu meningkatkan rasa ingin tahu mereka, sehingga keinginan siswa untuk belajar menjadi meningkat.

Perubahan pola pembelajaran yang berbeda dari biasanya dapat mempengaruhi aktivitas belajar siswa. Situasi tersebut tercermin pada awal kerjasama yang terjadi pada kelompok belajar. Aktivitas dan motivasi siswa terhadap pembelajaran kooperatif model STAD-Problem Solving sangat baik. Berdasarkan pengamatan ketika pembelajaran berlangsung, siswa tampak antusias dalam melakukan diskusi sesama anggota kelompok. Semua anggota kelompok terlibat pada waktu memanipulasi alat peraga. Mereka terlihat semangat lagi dan gembira mereka ketika diskusi kelompok dibuat model permainan dengan kompetisi antar kelompok.

Meningkatnya pemahaman atau hasil belajar siswa disebabkan pengalaman-pengalaman yang diberikan melalui pembelajaran. Pada tahap ini, siswa belajar menemukan konsep melalui peragaan. Hal ini didukung pendapat Bruner (dalam Dahar, 19$88: 125)$ yang menyatakan bahwa berusaha sendiri untuk menemukan pengetahuan akan menghasilkan pengetahuan yang benarbenar bermakna. Lebih lanjut Ausubel (dalam Dahar, 1988:141) mengatakan bahwa pengetahuan yang dipelajari secara bermakna dapat diingat lebih lama.

Dalam penelitian ini, anak-anak dibiasakan memecahkan masalah yang lumayan rumit bila mereka terbiasa dibimbing menggunakan istilah-istilah yang akrab dan konkrit bagi mereka, walaupun seringkali juga gagal menjawab soal yang sama jika soal itu disajikan dalam bentuk abstrak. Oleh karena itu, dalam proses pembelajaran, anak-anak harus sering diajak untuk memecahkan masalah yang sesuai dengan tingkat usia dan pengalaman yang mereka dapat. Jika anak dibiasakan memecahkan masalah, maka ini akan membangun gudang pengalaman anak yang kelak dapat mereka gunakan untuk memecahkan masalahmasalah berikutnya. Hal ini sependapat dengan Shapiro (1997: 141), yang mengutip hasil penelitian yang menyatakan bahwa anak-anak jauh lebih ahli dalam memecahkan masalah jauh dari yang diduga oleh kebanyakan orang. Ia menyimpulkan bahwa pemecahan masalah yang berhasil tidak begitu bergantung kepada kecerdasan si anak, akan tetapi lebih kepada pengalaman mereka.

\section{KESIMPULAN}

Berdasarkan hasil penelitian dan pembahasan sebelumnya, secara umum dapat disimpulkan bahwa penerapan pembelaja- 
ran dengan model STAD-Problem Solving dapat meningkatkan kualitas proses pembelajaran dan hasil belajar matematika siswa kelas IV SD Muhammadiyah 8 Dau Malang.

Dengan mengacu kepada tujuan penelitian ini, disimpulkan bahwa: (1) penerapan pembelajaran Model STAD-Problem Solvi$n g$ dapat menghasilkan desain model pembelajaran yang baik. Adapun langkah-langkah pembelajarannya adalah sebagai berikut: fase 1. persiapan, fase 2. Penyajian informasi (Garis Besar Materi Pelajaran) ke arah Problem Solving, fase 3. Bekerja kelompok, fase 4. memberikan Tes/kuis, fase 5. memberikan skor perkembangan, Fase 6 . memberikan penghargaan pada kelompok, yang meliputi; Penghargaan untuk kelompok bisa berupa tanda mata, pujian, atau status (misalnya, kelompok terbaik), (2) pelaksanaan pembelajaran dengan model STAD-Problem Solving dapat meningkatkan kualitas proses pembelajaran, dengan ditandai meningkatnya keaktivan belajar siswa, kreativitas siswa, rasa senang siswa dalam belajar dan kualitas interaksi dalam proses pembelajaran. (3) Hasil belajar matematika siswa dengan menggunakan model STADProblem Solving dapat meningkat. Hal ini dibuktikan dengan adanya peningkatan hasil belajar siswa dari siklus I ke siklus II.

\section{DAFTAR PUSTAKA}

Akbar, Sa'dun. 2009. Penelitian Tindakan Kelas .Cipta Media Aksara, Yogyakarta.

Billstein, R, etc. 2010. A Problem Solving Approach to Mathematic for Elementary School Teachers.

Dahar, R.W. 1988. Teori-teori Belajar. Jakarta: Dedikbud P2LPTK.

Depdiknas. 2006. Permendiknas Nomor 22 Tahun 2006 Tentang Standar Isi Sekolah Dasar. Jakarta: Depdiknas
Driver R, etc., 1994. Constructing Scientific knowledge in the classroom. Educational Researcher, 23(7),5-12

Gabel, D. 1999. Improving Teaching and Learning through Chemestry Education Research: ALook to the Future. Journal of Chemestry Education. Vol 76(4), 548-554

Hudoyo, H. 1998. Mengajar Belajar Matematika. PPLPTK Jakarta.

Hudoyo, H.2001. Pengembangan Kurikulum dan Pembelajaran Matemati$k a$. Jurusan Pendidikan Matematika Universitas Negeri Malang.

Johnstone, Alex H. 2000. Teaching of Physics-logical or psychological? Phy sics Educatin: Research and Practice in Europe, Vol.1(1), 9-15.

Polya,G.1973. How to Solve It ( $2^{\text {nd }}$ Ed). Princeton: Princeton University Press.

Slavin, R. E. 1994. Education Psycology Theory Into Practice. Edisi 4. Booston: Allyn and Bacon.

Slavin, R.E. 2008. Education Psycology Theory and Practice (psikologi pendidikan Teori dan Praktek). Terjemahan Marianto Samosir. Edisi 8. Jakarta: PT Indeks

Slavin, R.2010. Cooperative Learning. Teori, Riset dan Praktek. Nusa Media: Bandung.

Solikhati. 2009. Peningkatan Hasil Belajar Matematika Melalui Model Pembelajaran Kooperatif Tipe STAD. JPMS (Jurnal pendidikan Matematika dan Sains). Vol 14 No 1.

Sumarno, Alim. 2011. Peningkatan Pembelajaran Matematika berorientasi Open-Ended Problem Solving untuk Meningkatkan Kualitas Proses dalam Pemecahan Masalah Pada Siswa SD Kelas $V \mathrm{Ba}$ nyuasri. Jurnal Alternatif. Vol 8 No 2.

Supriyatiningsih, Endang. 2008. Melalui Penerapan Strategi Belajar Koo- 
36 Jurnal Pemikiran dan Pengembangan, Jilid 1, Nomor 1, April 2013, hlm. 29-36

peratif Tipe STAD Bagi Siswa Kelas VI SD Negeri 1 Godong Hasil Belajar Matematika Meningkat.
Jurnal Widyatama (Jurnal Pemikiran Pendidikan). Vol 5 No 4. 